\title{
Identification of Viruses from Potato Planted in Winter in Guangxi by Small RNA Deep Sequencing
}

\author{
Jingjing Song \\ Qinzhou University, Qinzhou 535011, China \\ Guangxi University, Nanning 530004, China
}

\begin{abstract}
Objective] The objective of this study is to identify viruses infecting potato planted in winter in Guangxi for establishing a future healthy potato seed program and better disease control in the field. [Method] One hundred and nine samples with viral disease-like symptoms were collected from potato plants in the fields in 2012 and analyzed by small RNA deep sequencing. [Result] Potato leafroll virus (PLRV), Potato virus A (PVA), Potato virus H (PVH), Potato virus M (PVM), Potato virus S (PVS), Potato virus Y (PVY), and Potato spindle tuber viroid (PSTVd) were detected in the samples.[Conclusion]Potato planted in winter in Guangxi were infected with many viruses including two viruses and a viroid that had not been reported in the region before. Thus, a virus-free healthy potato seed program is needed in urgency.
\end{abstract}

Keywords: Small RNA deep sequencing, Guangxi, Viruses disease.

\section{Introduction}

[Significance] As the world's fourth most-widely-consumed crop, potato is a very important food for everyday life and raw material for industry in China. The potato planted in winter in Guangxi has great potentials for making full use of fallow fields, enhancing multiple cropping index and satisfying market demand for fresh potato in winter. Although Guangxi's weather in winter is very suitable for growth of potato, low yield is still troubling and preventing good benefits as potato suffers from severe viral diseases. Hence, the identification of viruses from potato planted in winter in Guangxi is essential. [Previous Achievement] Now, there are around 40 viruses affecting potato [1] as reported in the world, including 6 viruses severely harmful to its yield, that is, Potato leafroll virus (PLRV), PVA, PVM, PVS, Potato virus X (PVX), and PVY [2]. For its reproduction through tubers, potato is more vulnerable to viruses that infect and deteriorate potato seed [3]. Among the method for detecting viruses of potato including biological technique and electron microscope, two methods, i.e. serological and molecular biological, have been favored for this purpose now [4-6]. In the serological method, fluorescence anti-body, enzyme linked immunoserbent assay (ELISA) and enzyme linked immunospot assay (ELISPOT) are often practiced [7-10]. Molecular biological method is based on polymerase chain reaction (PCR), but reverse transcription-polymerase chain reaction (RT-PCR) [11] and real time PCR (qRT-PCR) [12-13] are often conducted together with sequencing technique. Next generation sequencing (NGS) featured by high throughput of data can be used to sequence DNA, total DNA and small DNA [14-15], so it has been applied in the identification and detection of viruses and viroids [16-19]. Unlike ELISA and PCR techniques, high-throughput sequencing can detect all viruses from samples without estimating the type of viruses beforehand. [Approach] In China, ELISA and RT-PCR techniques are frequently conducted to detect the viral diseases of potato, showing some limitations for their reliance on known viruses. This study introduces the small RNA deep sequencing for detecting viral diseases in a large size of samples from potato planted in winter in Guangxi, with an aim to identify the viruses missed in the previous detection with ELISA and RT-PCR techniques. [Key Issue] All viruses infecting potato planted in winter in Guangxi are identified together with dominant potato seed to guide the prevention and control of viral diseases for potato in Guangxi. 


\section{Material and Method}

The test was completed at the State Key Laboratory for Conservation and Utilization of Subtropical Agro-bioresources in Guangxi University in February-August 2012.

\subsection{Material}

In main planting regions of potato (Qinzhou, Nanning, Guigang and Yulin), one hundred and nine samples with viral disease-like symptoms were collected from potato varieties, including mostly Favorita, and partially Black Beauty, Atlantic and Cooperation 88, etc.

\subsection{Method}

2.2.1 Field survey and sample collection. From the fields with large-scale production, potato plants with typical symptoms were collected based on the incidence determined by taking five samples on diagonal, and then grew in greenhouse. The 109 samples collected were classified into 8 categories in terms of mosaic, rolling, dark green and no branching, shrinkage, yellowish, lightning-shape, waxed and thickened leaves, vein necrosis.

2.2.2 Extraction of total RNA. Based on the operating instructions, TRNzol-A+ total RNA extraction kit (Tiangen Biotech (Beijing) Co., Ltd.) were used to extract total RNA of potato. The quality of RNA was tested by $1 \%$ agarose gel electrophoresis, which was stored at $-80^{\circ} \mathrm{C}$.

2.2.3 Small RNA deep sequencing and sequence analysis. Small RNA library preparation kit was purchased from Illumina. Eight sample pools for symptoms were built separately or jointly into 5 cDNA library pools (Table 1). In each library pool, total RNA samples were mixed equally. Small RNA samples were prepared as specified in the instructions for preparing Illumina Small RNA v1.5 samples. After reverse transcription of total RNA with adapter and primer, PCR was amplified by using adapters and primers into 14 cycles. Subsequently, 6\% PAGE gel was used in separation by electrophoresis, and gel was digested to recycle 93-105 nt fragments (including 75nt long adapter). Purification generated the cDNA library with

Table 1 cDNA libraries and their use in small RNA sequencing

\begin{tabular}{|c|c|c|c|c|}
\hline $\begin{array}{c}\text { Sequencing } \\
\text { lane }\end{array}$ & cDNA library & Sample symptom & Collection site & $\begin{array}{c}\text { Sample } \\
\text { number }\end{array}$ \\
\hline Lane 1 & Library 1 & Mosaic & $\begin{array}{c}\text { Qinzhou, Nanning, } \\
\text { Guigang, Yulin }\end{array}$ & 22 \\
\hline Lane 2 & Library 2 & Rolling & $\begin{array}{c}\text { Qinzhou, Nanning, } \\
\text { Guigang, Yulin }\end{array}$ & 30 \\
\hline Lane 3 & $\begin{array}{c}\text { Library 3, } \\
\text { Library 4 }\end{array}$ & Dark green and no branching, shrinkage & $\begin{array}{c}\text { Qinzhou, Guigang, } \\
\text { Yulin }\end{array}$ & 35 \\
\hline Lane 4 & Library 5 & $\begin{array}{c}\text { Yellowish, lightning-shape, waxed and } \\
\text { thickened leaves, vein necrosis }\end{array}$ & $\begin{array}{c}\text { Qinzhou, Nanning, } \\
\text { Guigang, Yulin }\end{array}$ & 22 \\
\hline
\end{tabular}

Sequencing primers and adapters. Qubit (Invitrogen) fluorometer was used to measure the concentration of cDNA library, and then cluster generation was carried out on cBot. After that, Illumina Genome Analyzer GX II was used for deep sequencing. The software CLC Genomics Workbench5 was employed to perform the assembly and alignment analysis on the obtained data of small RNA sequencing.

\section{Result}

Small RNA sequences obtained from CLC Genomics Workbench5 were used in contig assembly, and compared with virus and viroid sequences in GenBank to find out their coverage (Table 3). This revealed 6 viruses including PLRV, PVA, PVH, PVM, PVS and PVY and 1 viroid PSTVd. Among them, PVY had the largest number of reads (more than five million) in the high-throughput sequencing, which was followed by PVA (more than one million) and PVM (more than four hundred thousand). There were more than seven thousand reads of the viroid PSTVd. As samples were combined based on the type of symptom (each sequencing lane represents a type of symptom in Table 1 ), it was concluded that a type of symptom clearly corresponded to a specific kind of virus. PVY appeared more frequently in the samples with different symptoms, e.g. 94.36\% in rolling (Lane 2), 72.03\% in mosaic (Lane 1), and $44.44 \%$ in Lane 3. Five viruses including PLRV, PVA, PVH, PVM 
and PVS, mainly appeared primarily in Lane 3, and less frequently in Lane 1. PSTVd appeared primarily in Lane 3, accounting for $0.21 \%$, followed by Lane 4, accounting for $0.05 \%$.

Table 2 Number and percentage of small RNA reads of viruses identified

\begin{tabular}{|c|c|c|c|c|c|c|c|}
\hline $\begin{array}{c}\text { Sequencing } \\
\text { lane }\end{array}$ & PLRV & PVA & PVH & PVM & PVS & PVY & PSTVd \\
\hline Lane 1 & $\begin{array}{c}19007 \\
(1.23 \%)\end{array}$ & $\begin{array}{c}195201 \\
(12.67 \%)\end{array}$ & $\begin{array}{c}27882 \\
(1.81 \%)\end{array}$ & $\begin{array}{c}144792 \\
(9.40 \%)\end{array}$ & $\begin{array}{c}23945 \\
(1.55 \%)\end{array}$ & $\begin{array}{c}1110071 \\
(72.03 \%)\end{array}$ & $\begin{array}{c}361 \\
(0.02 \%)\end{array}$ \\
\hline Lane 2 & $\begin{array}{c}4788 \\
(0.39 \%)\end{array}$ & $\begin{array}{c}30428 \\
(2.47 \%)\end{array}$ & $\begin{array}{c}4326 \\
(0.35 \%)\end{array}$ & $\begin{array}{c}16054 \\
(1.38 \%)\end{array}$ & $\begin{array}{c}3889 \\
(0.32 \%)\end{array}$ & $\begin{array}{c}1162250 \\
(94.36 \%)\end{array}$ & $\begin{array}{c}238 \\
(0.02 \%)\end{array}$ \\
\hline Lane 3 & $\begin{array}{c}36584 \\
(1.32 \%)\end{array}$ & $\begin{array}{c}899419 \\
(32.52 \%)\end{array}$ & $\begin{array}{c}57265 \\
(2.07 \%)\end{array}$ & $\begin{array}{c}295100 \\
(10.67 \%)\end{array}$ & $\begin{array}{c}120615 \\
(4.36 \%)\end{array}$ & $\begin{array}{c}1229194 \\
(44.44 \%)\end{array}$ & $\begin{array}{c}5835 \\
(0.21 \%)\end{array}$ \\
\hline Lane 4 & $\begin{array}{c}5496 \\
(0.30 \%)\end{array}$ & $\begin{array}{c}9967 \\
(0.57 \%)\end{array}$ & $\begin{array}{c}11484 \\
(0.62 \%)\end{array}$ & $\begin{array}{c}56648 \\
(3.07 \%)\end{array}$ & $\begin{array}{c}34986 \\
(1.90 \%)\end{array}$ & $\begin{array}{c}1698351 \\
(92.08 \%)\end{array}$ & $\begin{array}{c}913 \\
(0.05 \%)\end{array}$ \\
\hline
\end{tabular}

\section{Discussion}

\subsection{Structure and Source of Potato Viruses}

As discovered in the detection, a large range of potato plants were infected by PVY in most cases. The laboratory the author worked for had employed the virus-specific RT-PCR technique to detect the viral diseases from potato planted in winter in Yulin City in 2005[20], 2010 and 2011 respectively, consistently showing the highest prevalence of infection with PVY. Hence, the potato planted in winter in Guangxi was mostly infected by PVY in recent years. The survey in 2005 detected 5 viruses including PVY, PLRV, PVS, PVA and PVX. Apart from these viruses, it also detected PVH, PVM and PSTVd. PVH was a new virus infecting potato (JQ861257.1) discovered in Cambodia in March 2012.

\subsection{Contribution to Studies on Potato Viruses}

Healthy potato seed program plays a significant role in the prevention and control of potato viral diseases. For different types of viruses in potato seed at different places, it is especially important to strengthen the inspection and quarantine of potato seed at its place of origin. This study gives a detailed list of viruses in potato planted in winter in Guangxi, and provides a basis for the identification and prevention \& control of viruses in potato seed. For instance, apart from common viruses, PVH, PVM and viroid PSTVd must be added to the list for identification, even though it has not been discovered in Guangxi before. Meanwhile, these viruses will be taken as the target in the cultivation of anti-viral potato seed. This study identifies the high genetic diversity of PVS, which can also help explore the co-evolution of PVS and host plant from a new perspective.

\section{Conclusion}

Small RNA deep sequencing was employed to identify viral diseases in potato planted in winter in Guangxi, and detected 6 viruses including PLRV, PVA, PVH, PVM, PVS and PVY, and 1 viroid PSTVd. It is clearly concluded that potato seed infected by viruses must be the primary cause for the increased types of viruses in potato planted in winter in Guangxi in recent years, which provides a theoretical basis for prevention and control of viral diseases in potato in Guangxi. References

\section{References}

[1] Jeffries G J. FAO/IPGRI Technical Guidelines for the Safe Movement of Potato Germplasm: No 19, Potato. Rome: Food and Agriculture Organization of the United Nations, 1998: 33-96.

[2]Salazar L. Potato viruses after the XXth century: effects, dissemination and their control. Material Participants in Pyongyang Intern, Scientific Simp, on Potato, Pyongyang, DPRK, 2003: 35-42.

[3]Gao Y L, Zhang W, Bai Y J, Shen Y, Fan G Q, Geng H W, Liu W T. Investigation and analysis of viral diseases in main potato production areas. Plant Protection, 2011, 37(3): 149-151. (in Chinese) 
[4]Fang Z D. Research Methods of Plant Pathology. 3rd ed. Beijing: China Agriculture Press, 1998: 283-298. (in Chinese)

[5]Xie L H. General Plant Pathology. Beijing: Science Press, 2006: 274-282. (in Chinese)

[6]Xu B L, Cao K Q. Plant Pathology. Beijing: China Forestry Press, 2012: 126-127. (in Chinese)

[7]Banttari E E, Goodwin P H. Detection of potato viruses S, X, and Y by enzyme-linked immunosorbent assay on nitrocellulose membranes (dot-ELISA). Plant Disease, 1985, 69(3): 202-205.

[8]Lin N S, Hsu Y H, Hsu H T. Immunological detection of plant viruses and a mycoplasmalike organism by direct tissue blotting on nitrocellulose membranes. Phytopathology, 1990, 80(9): 824-828.

[9]Makkouk K M, Comeau A. Evaluation of various methods for the detection of barley yellow dwarf virus by the tissue-blot immunoassay and its use for virus detection in cereals inoculated at different growth stages. European Journal of Plant Pathology, 1994, 100(1): 71-80.

[10]Makkouk K, Kumari S. Molecular diagnosis of plant viruses. Arab Journal of Plant Protection, 2006, 24(2): 135-138.

[11]Barker H, McGeachy K D, Toplak N, Gruden K, Zel J, Browning I. Comparison of genome sequence of PVY isolates with biological properties. American Journal of Potato Research, 2009, 86(3): 227-238.

[12]Schaad N W, Frederick R D. Real-time PCR and its application for rapid plant disease diagnostics. Canadian Journal of Plant Pathology, 2002, 24(3): 250-258.

[13]Kogovšek P, Gow L, Pompe-Novak M, Gruden K, Foster G D, Boonham N, Ravnikar M. Single-step RT real-time PCR for sensitive detection and discrimination of Potato virus Y isolates. Journal of Virological Methods, 2008, 149(1): 1-11.

[14]Schuster S C. Next-generation sequencing transforms today's biology. Nature Methods, 2008, 5(1): 16-18.

[15]Li R, Gao S, Hernandez A G, Wechter W P, Fei Z, Ling K S. Deep sequencing of small RNAs in tomato for virus and viroid identification and strain differentiation. PLoS One, 2012, 7(5): e37127.

[16]Wu Q F, Luo Y J, Lu R, Lau N, Lai E C, Li W X, Ding S W. Virus discovery by deep sequencing and assembly of virus-derived small silencing RNAs. Proceedings of the Natural Academy of Sciences of the United States of America, 2010, 107(4): 1606-1611.

[17]Adams I P, Glover R H, Monger W A, Mumford R, Jackeviciene E, Navalinskiene M, Samuitiene M, Boonham N. Next-generation sequencing and metagenomic analysis: a universal diagnostic tool in plant virology. Molecular Plant Pathology, 2009, 10(4): 537-545.

[18]Al Rwahnih M, Daubert S, Golino D, Rowhani A. Deep sequencing analysis of RNAs from a grapevine showing Syrah decline symptoms reveals a multiple virus infection that includes a novel virus. Virology, 2009, 387(2): 395-401.

[19]Navarro B, Pantaleo V, Gisel A, Moxon S, Dalmay T, Bisztray G, Di Serio F, Burgyan J. Deep sequencing of viroid-derived small RNAs from grapevine provides new insights on the role of RNA silencing in plant-viroid interaction. PLoS One, 2009, 4(11): e7686.

[20]Chen B S, Meng J R, Cai J H, Wang H S, Chen J C, Wei X X. Investigation of Potato viruses planted in winter of Yulin in 2005. Plant Protection of Guangxi, 2006, 19(2): 1-2. (in Chinese ) 